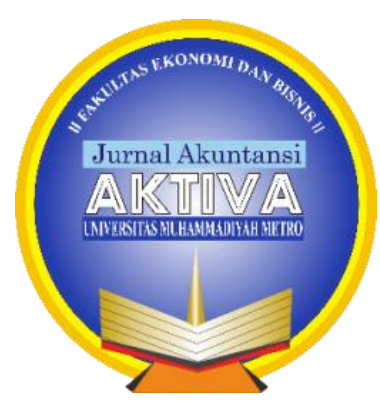

Jurnal Akuntansi AKTIVA, Vol 1, No. 2, Oktober 2020

\title{
ANALISIS PENERAPAN SISTEM INFORMASI AKUNTANSI PERSEDIAAN BARANG DI TOKO MP ONE STATIONARY 16C METRO BARAT
}

\author{
${ }^{1}$ Wahyu Nurlaila, ${ }^{2}$ Suyanto, ${ }^{3}$ Angga Kurniawan \\ Universitas Muhammadiyah Metro, Jl. Ki Hajar Dewantara, 34111, Lampung, Indonesia \\ Universitas Muhammadiyah Metro, Jl. Ki Hajar Dewantara, 34111, Lampung, Indonesia \\ Universitas Muhammadiyah Metro, Jl. Ki Hajar Dewantara, 34111, Lampung, Indonesia \\ Email: wahyunurlaila80@gmail.com, suyanto_140@yahoo.com, Angga.umm@gmail.com
}

\begin{abstract}
Wahyu, Nur, Laila 2020. "Application of Inventory Accounting Information System Goods in the MP One Stationary 16C Metro Barat (Case Study of 2017 FEB UM Metro Accounting Diploma Students) ". Faculty of Economics and Business, University of Muhammadiyah Metro. Advisors (1) Suyanto, S.E., M.Si.Akt.CA., ACPA., CRA. Advisors (2) Angga Kurniawan, S.E., M.Si.

In business activities in this globalization era, the development of information technology is indispensable to expand business networks and to facilitate internal corporate decision-making. The level of competition which is quite tight makes business actors more use of accounting information systems to manage their business activities properly.

This type of research is qualitative, namely research procedures that produce descriptive data in the form of words from the phenomena found in the field observed by the researcher. This study aims to determine the application of accounting information systems in the MP One Stationary 16C Metro Barat.

The results obtained from this study are the accounting information system implemented in the MP One Stationary Store along with the components that support the application of the Inventory Accounting Information System in the MP One Stationary Store.
\end{abstract}

Keywords : System, Information, Accounting

\begin{abstract}
ABSTRAK
Wahyu, Nur, Laila 2020. "Penerapan Sistem Informasi Akuntansi Persediaan Barang di Toko MP One Stationary 16C Metro Barat (Studi Kasus Mahasiswa DIII Akuntansi FEB UM Metro Tahun 2017)". Fakultas Ekonomi dan Bisnis Universitas Muhammadiyah Metro. Pembimbing (1) Suyanto, S.E.,M.Si.Akt.CA.,ACPA.,CRA. Pembimbing (2) Angga Kurniawan, S.E.,M.Si.
\end{abstract}

Dalam kegiatan bisnis di era globalisasi ini, perkembangan teknologi informasi sangat diperlukan untuk memperluas jaringan usaha dan untuk mempermudah dalam pengambilan keputusan pihak internal perusahaan. 
Tingkat persaingan yang cukup ketat membuat para pelaku usaha lebih memanfaatkan sistem informasi akuntansi untuk mengelola kegiatan usaha nya dengan baik.

Jenis penelitian ini adalah kualitatif yaitu prosedur penelitian yang mmenghasilkan data deskriptif berupa kata-kata dari fenomen yang ditemukan di lapangan yang diamati oleh peneliti. Penelitian ini bertujuan untuk mengetahui penerapan sistem informasi akuntansi di Toko MP One Stationary 16C Metro Barat.

Hasil yang diperoleh dari penelitian ini adalah sistem informasi akuntansi yang diterapkan di Toko MP One Stationary beserta komponen-komponen yang mendukung penerapan Sistem Informasi Akuntansi Persediaan Barang di Toko MP One Stationary.

Kata Kunci : Sistem, Informasi, Akuntansi

\section{PENDAHULUAN}

\section{Latar Belakang}

Perkembangan teknologi informasi dan komunikasi di Indonesia telah mengalami kemajuan yang sangat pesat. Teknologi informasi dan komunikasi sudah sedemikian maju dengan banyak digunakannya peralatan komunikasi yang berukuran kecil tetapi memiliki kinerja yang cukup menguntungkan. Dahulu banyak daerah terpencil yang tidak terjamah oleh teknologi informasi dan komunikasi, kini mereka yang berada di daerah terpencil sudah dapat merasakan keberadaan dari teknologi informasi dan komunikasi yang sudah maju. Salah satu contoh yang menjadi pemicu terjadinya perkembangan teknologi informasi dan komunikasi adalah laju perkembangan ilmu pengetahuan dan teknologi (IPTEK). Ilmu pengetahuan dan teknologi (IPTEK) semakin hari semakin pesat perkembangannya. Hal tersebut disebabkan adanya tuntutan dan kebutuhan manusia yang juga semakin berkembang diberbagai bidang.

Dengan diimbangi oleh semakin berkembangnya teknologi informasi, ekonomi, sosial dan budaya , secara tidak langsung kondisi ini akan mempengaruhi munculnya perekmbangan dari suatu sistem akuntansi. Di era saat ini perusahaan dituntut untuk memiliki sistem informasi akuntansi yang baik, dimana sistem informasi yang digunakan dapat dipertanggungjawabkan dan dapat diproses menjadi informasi yang berguna. Sistem informasi dapat dikatakan berguna jika didukung oleh tiga pilar yaitu : tepat pada orang yang menggunakan atau relevan, tepat waktu dan tepat nilainya atau akurat. Sehingga pengumpulan dan pengolahan data akan menjadi efektif dan efisien. Penerapan sistem informasi akuntansi persediaan barang akan membuat persediaan barang menjadi efektif dan efisien karena persediaan barang merupakan aktiva lancar yang berisiko tinggi. Pengendalian atas persediaan barang akan membantu perusahaan untuk mengurangi terjadinya kesalahan dalam penanganan jumlah barang yang tersedia. Jika pencatatan dan pengendalian jumlah barang persediaan telah dilakukan dengan baik dan benar sedini mungkin, maka penjumlahan dalam laporan keuangan akan menjadi benar. Untuk mengatasi masalah ini dan meminimalisir adanya kesalahan diperlukan suatu pengelolaan barang yang baik yang ditunjang dengan penyusunan sistem informasi akuntansi persediaan yang terfokus pada keluar masuknya persediaan barang dan pencatatan yang terjadi di perusahaan.

Sistem informasi akuntansi (SIA) merupakan kumpulan kegiatan-kegiatan dari organisasi yang bertanggung jawab untuk menyediakan informasi keuangan dan informasi yang didapatkan dari 
transaksi data untuk tujuan pelaporan internal kepada manajer untuk digunakan dalam pengendalian dan perencanaan sekarang dan operasi masa depan serta pelaporan eksternal kepada pemegang saham, pemerintah, dan pihak-pihak yang berkepentingan. Manfaat sistem informasi akuntansi bagi perusahaan yaitu menyediakan informasi yang akurat dan tepat sehingga berdampak pada kemajuan perusahaan, meningkatkan efisiensi pada perusahaan sehingga berdampak pada meningkatnya pendapatan, meningkatkan efisiensi kerja pada bagian keuangan perusahaan karena adanya sistem informasi akuntansi. Dengan adanya sistem informasi akuntansi perusahaan bias melakukan semua kegiatanny dengan efektif dan efisien. Selain itu output dari SIA juga dapat di pertanggungjawabkan dalam pengambilan keputusan.

Pada perusahaan yang berorientasi untuk mendapatkan laba, penjualan merupakan kegiatan utama untuk mencapai tujuan utama. Dalam rangka menunjang kegiatan penjualan, seorang manajer sangat berkepentingan atas informasi yang berkaitan dengan penjualan, untuk menyajikan informasi menganai penjualan sehingga dapat digunakan untuk mengambil keputusan lebih lanjut. Pada perusahaan jasa maupun manufaktur, penjualan sangat penting dan merupakan salah satu roda penggerak dalam kelangsungan hidup usaha perusahaan. Agar kegiatan penjualan dapat berjalan dengan efektif, tujuan perusahaan dapat tercapai sesuai dengan apa yang telah direncanakan, maka perlu adanya sistem informasi akuntansi.

Toko MP One Stationary merupakan perusahaan retail yang menjual perlengkapan alat tulis yang dijual secara grosir maupun ecer.Toko MP OneStationarymerupakan anak perusahaan dari CV Multi Papper Stationary yang saat ini sudah memiliki 8 karyawan. Toko MP One Stationary memiliki kapasitas persediaan yang besar, hal ini menyebabkan tingginya risiko keuangan atas persediaan barang yang ada. Karena menyediakan berbagai macam barang dengan jenis, bentuk, merk, ukuran, harga yang sifatnya berbeda-beda, barang dagang pada Toko MP One Stationary rentan terhadap berbagai kerusakan, keusangan, kelebihan maupun kekurangan persediaan serta kehilangan.

Kehilangan dan kerusakan barang dagang merugikan Toko MP One Stationary karena secara otomatis mengurangi jumlah persediaan barang dagang yang berdampak kepada pengurangan profit yang seharusnya diterima oleh Toko MP One Stationary. Selain itu akan menyebabkan hilangnya kepercayaan konsumen atau pihak lain yang berkepentingan.

Berkaitan dengan latar belakang yang telah dipaparkan, maka peneliti tertarik untuk mengambil judul Analisis Penerapan Sistem Informasi Akuntansi Persediaan Barang di Toko MP One Stationary.

\section{Perumusan Masalah}

Berdasarkan Berdasarkan uraian diatas maka ada permasalahan-permasalahan yang berkaitan dengan sistem akuntansi persediaan barang. Adapun yang menjadi pokok permasalahan dalam Tugas Akhir ini adalah :

1. Apakah Toko MP One Stationary Sudah Menerapkan Sistem Informasi Akuntansi persediaan barang berbasis aplikasi? 
2. Apakah Komponen-komponen Sistem Informasi Akuntansi Persediaan Barang berbasis aplikasi yang Diterapkan di Toko MP One Stationary?

\section{Tujuan Penelitian}

Tujuan yang ingin di capai dari penelitian ini adalah :

1. Untuk Mengetahui Apakah Toko MP One Stationary sudah Menerapkan Sistem Informasi Akuntansi Persediaan Barang berbasis aplikasi.

2. Untuk Mengetahui Komponen-komponen Sistem Informasi Akuntansi Persediaan Barang berbasis aplikasi yang diterapkan di Toko MP One Stationary

\section{LANDASAN TEORI}

\section{Pengertian Sistem Informasi Akuntansi Persediaan}

Menurut Krismiaji (2015:367) sistem informasi akuntansi persediaan adalah suatu sistem yang mengorganisir catatan persediaan yang dapat memberi tahu manajer apabila jenis barang tertentu memerlukan penambahan. Sehingga, dapat dikatakan bahwa sistem persediaan merupakan sebuah sistem yang memproses data dan transaksi untuk menghasilkan informasi yang bermanfaat terkait persediaan barang. Sistem informasi akuntansi dapat mengetahui aktivitas pembelian, penerimaan, dan penjualan barang jadi oleh perusahaan. Dapat digunakan sebagai control bagi perusahaan, sehingga perusahaan dapat mengetahui jenis barang yang sedang laku dipasaran.

\section{Komponen Sistem Informasi Akuntansi}

Komponen sistem informasi akuntansi terdiri dari beberapa bagian yang membentuk sebuah sistem. Menurut Romney dan Steinart (2015:3), yaitu :

1. People

Merupakan pengguna sistem yang mengoperasikan sistem informasi dan membutuhkan informasi yang dihasilkan oleh sistem informasi. Dalam sistem informasi persediaan, pengguna sistem adalah karyawan atau pemilik yang mengoprasikan sistem informasi, dan pihak lainnya yang menerima informasi yang dihasilkan oleh sistem informasi persediaan.

\section{Procedures}

Merupakan langkah atau instruksi yang digunakan untuk mengumpulkan, memproses, dan menyimpan data. Dalam sistem informasi persediaan, langkah atau instruksi (Procedures) adalah tahapan-tahapan yang dilakukan oleh perusahaan baik itu secara fisik atau nyata, dan digital atau komputerisasi untuk mengumpulkan data persediaan, mengolah data persediaan menjadi informasi persediaan dan penyimpanan data dan informasi persediaan. 


\section{Data}

Merupakan informasi yang didalamnya berisi tentang aktivitas bisnis organisasi yang perlu dikumpulkan, diproses, dan disimpan oleh sistem informasi. Dalam sistem informasi persediaan, data adalah catatan persediaan yang didalamnya terdiri dari nama atau jenis persediaan dan jumlahnya, yang bila belum diolah oleh sistem informasi belumdapat menghasilkan persediaan yang utuh.

4. Software

Merupakan perangkat lunak yang digunakan untuk memproses data organisasi dan menghasilkan informasi yang dibutuhkan oleh pengguna sistem. Dalam sistem informasi persediaan, software adalah perangkat lunak yang digunakan perusahaan untuk membantu mencatat, mengolah, dan menyajikan informasi persediaan, serta menyimpan informasi persediaan secara digital.

5. Information Technology Infrastucture

Merupakan perangkat keras teknologi informasi, yang terdiri dari komputer, peralatan pendukung (peripheral device), dan peralatan untuk komunikasi jaringan. Dalam sistem informasi persediaan perangkat keras teknologi informasi adalah sebuah serangkaian perangkat kerasyang digunakan perusahaan sebagai alat bantu teknologi terkomputerisasi.

6. Internal Control and Security

Merupakan langkah-langkah pengendalian internal dan keamanan yang dilakukan untuk melindungi siste informasi dan menjamin bahwa sistem informasi berjalan dengan baik dan benar.

\section{HASIL DAN PEMBAHASAN}

Sistem ACOSYS V4 adalah software akuntansi Indonesia yang memiliki fitur sederhana dan dapat digunakan oleh perusahaan dengan bisnis yang lebih spesifik. ACOSYS V4 dikembangkan oleh PT Acosys Global data yang sudah pengalaman >11 tahun di Indonesia. Keunggulan dari sistem ACOSYS V4 ini adalah dapat memenuhi perusahaan yang multi bisnis, mencakup toko, minimarket, supermarket, grosir, supplier, apotek, optik, salon kecantikan, klinik kesehatan, rumah sakit, rumah makan, perusahaan manufaktur dll.

Terdapat begbagai fitur-fitur akuntansi yang dapat membantu perusahaan bisnis dalam membuat prosedur akuntansi dengan mudah dan efisien. Sistem ACOSYS didirikan di Lampung, dan menjadi sistem akuntansi pertama yang didirikan di Lampung. 


\section{Keunggulan Aplikasi ACOSYS}

Berdasarkan hasil dari penelitian dan wawancara yang dilakukan dengan kepala toko dan kasir di Toko MP One Stationary terdapat keunggulan dan kelemahan dalam penggunaan Aplikasi ACOSYS. Keunggulan dari aplikasi ACOSYS yaitu :

1. Data-data transaksi terorganisasi dengan Baik

Membuat laporan keuangan secara manual tentu memiliki risiko seperti hilangnya faktur dan salah pencatatan. Namun, dengan menggunakan aplikasi ACOSYS, maka hal-hal tersebut dapat dihindari karena pencatatan dilakukan secara digital serta terkumpul dengan aman dan terorganisasi dengan baik.

2. Mudah dipahami

Salah satu keunggulan dari aplikasi ACOSYS adalah mudah digunakan, karena fiturfiturnya yang mudah dipahami. Bahkan untuk pengoperasiannya juga bias dilakukan oleh mereka yang tidak berlatar belakang dibidang akuntan.

3. Laporan Real Time

Berbeda dengan cara manual yang pencatatan transaksi biasanya diolah menjadi laporan keuangan diakhir tahun maka dengan aplikasi, hal ini bisa dilakukan secara otomatis, sehingga hasil laporannya real-time. Hasilnya pihak internal toko dapat melakukan evaluasi kapanpun sehingga masalah bias diatasi secepatnya.

4. Hemat waktu dan tenaga

Pada saat pembuatan laporan keuangan secara manual akan memerlukan waktu yang cukup lama. Namun, jika dengan menggunakan software akuntansi apabila terdapat transaksi maka akan otomatis masuk kedalam laporan keuangannya.

\section{Kelemahan dari aplikasi ACOSYS yaitu:}

1. Membutuhkan koneksi server yang baik

Aplikasi di Toko MP One Stationary dijalankan secara terpusat, maka jika server mengalami down maka sistem software tidak bisa berjalan dengan lancar.

2. Harga yang cukup mahal

Dalam satu aplikasi Akuntansi dijual berdasarkan fitur-fitur yang ada. Hal ini menyebabkan harga persatuan fitur software akuntansi cukup mahal. Dan biaya maintenance yang cukup besar.

3. Sering mengalami bug

Software ACOSYS sering mengalami ketidakcocokan kuantitas barang yang didisplay dan barang digudang ketika pengecekan arus persediaan. Hal ini mempengaruhi laporan persediaan yang ada. 
Berdasarkan hasil dari penelitian ini, dapat disimpulkan bahwa Toko MP One Stationary sudah memanfaatkan tekonlogi komputer dengan baik. Namun masih terdapat kelemahan mengenai persediaan dalam software akuntansi yang digunakan.

Fungsi yang terkait dengan sistem informasi akuntansi persediaan barang di Toko MP One Stationary. Berdasarkan hasil penelitian yang telah dilakukan, fungsi-fungsi yang terkait dengan sistem informasi akuntansi persediaan barang di Toko MP One Stationary terdiri dari fungsi gudang, fungsi pembelian, fungsi penerimaan barang, dan fungsi akuntansi.

Dokumen yang terkait dengan sistem informasi akuntansi persediaan barang di Toko MP One Stationary. Berdasarkan hasil penelitian yang dilakukan, dokumen yang terkait dengan sistem informasi akuntansi persediaan barang di Toko MP One Stationary yaitu surat order pembelian, faktur pembelian, dan nota retur pembelian.

Catatan yang terkait dengan sistem informasi akuntansi persediaan barang di Toko MP One Stationary. Berdasarkan hasil penelitian yang dilakukan, catatan yang terkait dengan sistem informasi akuntansi persediaan barang di Toko MP One Stationary yaitu form daftar barang masuk dan catatan persediaan.

Prosedur sistem informasi akuntansi persediaan barang di Toko MP One Stationary. Berdasarkan hasil penelitian, prosedur yang terkait dengan sistem informasi akuntansi persediaan adalah prosedur permintaan pembelian. Dimana pemilik, kepala toko, pramuniaga melakukan pengecekan barang (stock opname) dengan cara mengecek arus persediaan dan mengecek fisik persediaan yang ada, pengecekan ini dilakukan setiap sebulan sekali. Dengan batas minimal 24 pieces per-item barang yang harus diorder kembali. Kemudian, pemilik membuat daftar barang yang harus diorder dan mengirimkan surat yang berisi daftar barang yang harus diorder kepada pemasok. Lalu pemasok menyiapkan barang yang sudah dipesan oleh pemilik dan mengirimkan barang sesuai dengan surat order pembelian beserta faktur pembelian. Prosedur penerimaan barang, yaitu barang yang telah dikirimkan oleh pemasok beserta faktur pembelian kepala toko akan menerima faktur pembelian dan menyimpan faktur pembelian serta membayarkan kepada pemasok. Setelah itu kepala toko akan membuat catatan persediaan sesuai dengan faktur penjualan. Kemudian, barang tersebut akan dicek oleh pramuniaga terkait dengan kuantitas, merk, warna, bentuk, harga dan ukuran apakah sesuai dengan catatan persediaan yang dibuat oleh kepala toko. Kemudian, Prosedur penyimpanan barang yaitu catatan persediaan yang dibuat oleh kepala toko akan dijadikan pedoman untuk fungsi gudang, kemudian fungsi gudang akan membuat rekap persediaan yang masuk ke gudang.

Bagan alir sistem informasi akuntansi pembelian persediaan barang di Toko MP One Stationary. Fungsi pembelian (pemilik) melakukan transaksi pembelian kepada pemasok, setelah pemilik melakukan transaksi pembelian maka pemasok akan mengirimkan bukti pembelian dan barang yang dibeli oleh fungsi pembelian. Bukti pembelian akan dicatat dan diarsipkan oleh kepala toko (bagian akuntansi). Lalu catatan persediaan yang dibuat oleh kepala toko akan diserahkan kebagian gudang untuk mengecek keseuaian kuantitas, jenis, merk, ukuran, warna yang dipesan oleh 
fungsi pembelian. Setelah fungsi gudang mengecek kesesuaian barang yang dipesan makan pihak gudang bertanggung jawab untuk mencatat rekapitulasi persediaan yang baru dibeli oleh fungsi pembeli.

\section{KESIMPULAN DAN SARAN}

\section{Kesimpulan}

Berdasarkan hasil dari penelitian yang telah dilakukan diatas, dapat disimpulkan bahwa :

Sistem Informasi Akuntansi di Toko MP One Stationary sudah menggunakan sistem komputerisasi dengan baik. Namun terdapat kekurangan mengenai persediaan yang dialami sistem ACOSYS yaitu menginput kembali stock yang sebenarnya sudah habis yang menyebabkan ketidakseimbangan pada Laporan keuangan. Penerapan sistem informasi akuntansi persediaan di Toko MP One Stationary yaitu dari fungsi yang terkait dengan sistem informasi akuntansi persediaan barang yaitu, fungsi gudang, fungsi pembelian, fungsi penerimaan barang dan fungsi akuntansi. Catatan dan dokumen yang dibutuhkan yaitu : form barang masuk dan catatan persediaan. Prosedur yang digunakan yaitu prosedur permintaan pembelian, prosedur order barang, prosedur penerimaan barang dan prosedur penyimpanan dan pencatatan persediaan.

Berdasarkan penelitian enam komponen yang digunakan di Toko MP One Stationary yaitu People, Procedures, Data, Software, Information Technology Infrastucture, dan Internal Control and Security. Dari keenam komponen tersebut komponen Internal Control and Security masih lemah, dimana fungsi akuntansi masih menjadi satu dengan fungsi kepala toko, sehingga membuat fungsi kepala toko tidak efisien.

\section{Saran}

Berdasarkan penelitian diatas, peneliti memberikan saran pada Toko MP One Stationary yaitu :

1. Perkembangan sistem informasi akuntansi persediaan barang di Toko MP One Stationary sudah canggih dan mampu memenuhi kebutuhan. Meskipun pernah terdapat kesalahan mengenai persediaan yang di sebabkan oleh sistem. Toko MP One Stationary sebaiknya menangani atau memperbaiki sistem persediaan yang ada, agar tidak terdapat keselisihan terhadap laporan keuangan nantinya.

2. Sebaiknya Toko MP One Stationary lebih memperhatikan efektifitas pengendalian intern dalam pemisahan fungsi-fungsi terkait, sehingga mampu meminimalisir adanya kesalahan maupun kecurangan. 


\section{DAFTAR PUSTAKA}

Jogiyanto, H.M., 2005, Analisa dan Desain Sistem Informasi: Pendekatan Terstruktur Teori dan Praktik Aplikasi Bisnis, ANDI, Yogyakarta.

Krismiaji, (2015), “Sistem Informasi Akuntansi”, Edisi keempat, UPP STIM YKPN,Yogyakarta.

Mulyadi. (2016). Sistem Informasi Akuntansi. Jakarta: Salemba Empat.

Mulyadi. 2008. Sistem Akuntansi. Jakarta: Salemba Empat.

Romney, Marshall B. dan Steinbart, (2015), “Sistem Informasi Akuntansi”, Edisi 13, alihbahasa: Kikin Sakinah Nur Safira dan Novita Puspasari, Salemba Empat, Jakarta.

Warren, Reeve, dan Fess. 2006. Pengantar Akuntansi. Jakarta: Salemba Empat.

Wilkinson, Joseph W den Cerullo, Michael J, 2000, Accounting Information System, Essential Concept and Aplication, fourth edition, John Wiley \& Sons, Inc, USA. 